\title{
Molecular mass and isoelectric properties of pituitary and urinary gonadotrophins in callitrichid primates
}

\author{
J. Rosenbusch, A. Bellmann and J. K. Hodges \\ Department of Reproductive Biology, German Primate Centre, Kellnerweg 4, D-37077 Göttingen, \\ Germany
}

\begin{abstract}
In this study, the molecular masses and isoelectric characteristics of pituitary LH and FSH in two species of callitrichid primate, the common marmoset (Callithrix jacchus) and the cotton-top tamarin (Saguinus oedipus), were determined. Comparative data for urine samples from Callithrix jacchus are also presented. The separation of gonadotrophins from pituitary extracts and urine was performed under nonreducing conditions using SDS-PAGE and isoelectric focusing procedures. Hormone activity in gel eluates was determined by in vitro bioassays for LH and FSH and by a microtitre plate enzymeimmunoassay for LH. The molecular masses of pituitary and urinary proteins were between 36 and $37 \mathrm{kDa}$ for $\mathrm{LH}$ and $\mathrm{FSH}$, and were similar in both species. A dimer form of pituitary LH with a molecular mass of $33 \mathrm{kDa}$ was also found in the cotton-top tamarin, but not in the marmoset. Guanidine- $\mathrm{HCl}$ dissociation of gonadotrophins from marmoset and tamarin pituitaries before electrophoresis gave proteins of 16 and $28 \mathrm{kDa}$, and 16 and $25 \mathrm{kDa}$ range, respectively. Isoelectric focusing revealed numerous peaks of bioactivity for both $\mathrm{LH}$ and $\mathrm{FSH}$, indicating the presence of multiple molecular variants (isoforms) of each hormone. In both species pituitary FSH eluted over a narrower and more acidic $\mathrm{pH}$ range than $\mathrm{LH}$. Isoelectric focusing profiles for pituitary and urinary $\mathrm{LH}$ in the marmoset were similar $\mathrm{pH}$ range 5.0-8.5), whereas urinary FSH demonstrated a more acidic profile than the pituitary protein. These results give comparative information on the properties of New World primate gonadotrophins, which should be useful in studies of their physiological action and in aiding the development of improved reagents and assays for their detection.
\end{abstract}

\section{Introduction}

Information on the biochemical properties of pituitary gonadotrophins is essential for basic studies on structure-function relationships and for the development of reagents and methods to detect these hormones in physiological studies. Among the nonhuman primates, however, there is little information about even the basic characteristics of either LH or FSH and the only detailed information has been provided for the rhesus macaque (Macaca mulatta) by Matteri and co-workers (Matteri and Zeigler, 1992; Matteri et al., 1992). In these studies, data on the molecular mass and isoelectric properties of pituitary gonadotrophins were presented based on the use of a novel approach involving nonreducing SDS-PAGE and isoelectric focusing (IEF) followed by hormone assay of gel eluates.

Among the New World primates, Callitrichidae are of particular scientific interest owing to the value of certain species in biomedical research and because of the need to develop improved methods of captive breeding for several others that are threatened or endangered in the wild. Physiological studies in these species have been somewhat hampered by the lack of appropriate hormone assays, particularly for the detection of pituitary gonadotrophins. Furthermore, reliable ovarian stimulation protocols, useful in the implementation of assisted reproductive strategies, are not available; this is at least partly due to the absence of suitable (homologous) gonadotrophin preparations. The only information on the properties of gonadotrophic hormones in callitrichid primates is provided in a preliminary report of the molecular mass of urinary LH in the cotton-top tamarin Saguinus oedipus (Ziegler and Matteri, 1991).

The aims of the present study were therefore to provide initial comparative information on the properties of pituitary and urinary gonadotrophins in callitrichid primates. Using the approach described by Matteri and Ziegler (1992), we report on the molecular mass and isoelectric properties of pituitary $\mathrm{LH}$ and FSH in the common marmoset (Callithrix jacchus) and cotton-top tamarin, and also provide data on urinary gonadotrophins in the marmoset for comparison. This information should aid subsequent attempts to produce recombinant or purified hormone preparations for further research on these and related New World primate species.

\section{Materials and Methods}

\section{Pituitary and urinary hormones}

Protein extracts were prepared from pituitary glands collected from animals that had been killed according to the 
guidelines set out by the German Tierschutzgesetz. The animals used were two female rhesus monkeys (adult nonpregnant), two female common marmosets (at day 7 of the follicular phase, each housed with a single male) and two cotton-top tamarins (adult breeding females, living in family groups). A reference preparation of human gonadotrophins (LER 907) was kindly provided by the National Hormone and Pituitary Program (NHPP, 5390).

Pituitaries were extracted and purified using a method similar to that described by Matteri and Ziegler (1992). In brief, pituitary tissue was minced on ice in $0.05 \mathrm{~mol}$ ammonium bicarbonate buffer $\mathrm{l}^{-1}$ containing $5 \mathrm{mmol}$ benzamidine $\mathrm{HCll}^{-1}$ and $1 \mathrm{mmol}$ phenylmethylsulfonyl fluoride $\mathrm{I}^{-\mathrm{I}}$ used as a protease inhibitor. The homogenized tissue was immediately desalted on a $1.2 \mathrm{~cm} \times 8 \mathrm{~cm}$ Sephadex G-25 (PD 10: Pharmacia, Heidelberg) column using ammonium bicarbonate $\left(0.05 \mathrm{~mol} \mathrm{l}^{-1}\right)$ as the elution buffer. Protein fractions were identified by absorbance at $450 \mathrm{~nm}$ and divided into portions for lyophilization before analysis. The final amounts of lyophilized protein obtained from each pituitary from the rhesus monkeys, marmosets and cotton-top tamarins were 0.7 and $0.84 \mathrm{mg}, 0.17$ and $0.19 \mathrm{mg}$, and 0.16 and $0.18 \mathrm{mg}$, respectively. Urinary proteins were prepared from urine samples collected in the early morning from the same two marmosets on days 5,6 and 7 of the follicular phase. Urine samples were pooled and divided into $1 \mathrm{ml}$ aliquots, to which $100 \mu \mathrm{l} 0.005 \mathrm{~mol}$ glycerol $\mathrm{l}^{-1}$ was added before freezing (Livesey et al., 1983). After thawing, urine samples were desalted and lyophilized as described for pituitaries. The final concentration of lyophilized protein was $0.12 \mathrm{mg} \mathrm{ml}^{-1}$ urine.

\section{Dissociation of gonadotrophin subunits}

Aliquots of marmoset and tamarin pituitary extract were incubated in $6 \mathrm{~mol}$ guanidine- $\mathrm{HCl} \mathrm{l^{-1 }}$ for $18 \mathrm{~h}$ at room temperature to induce dissociation of gonadotrophin subunits (Matteri and Papkoff, 1987), and desalted and lyophilized as described above.

\section{Electrophoresis of pituitary and urinary proteins}

SDS-PAGE. Pituitary and urinary proteins were separated on ready-to-use ExcelGel ${ }^{\text {(ii) }}$ SDS plates $(8-18 \%$ gradient; Pharmacia) using a nonreducing sample buffer (Swack et al., 1987; Matteri and Ziegler, 1992). Gels $(240 \mathrm{~mm} \times 120 \mathrm{~mm} \times 0.5 \mathrm{~mm})$ were precast and the electrophoresis was performed at a constant current of $50 \mathrm{~mA}$ (power cut off $30 \mathrm{~W}$ ) at $15^{\circ} \mathrm{C}$ for approximately $75 \mathrm{~min}$, or until the bromophenol blue front reached the anode. The anode strips contained $0.30 \mathrm{~mol}$ Tris $\mathrm{I}^{-1}$ and $0.30 \mathrm{~mol}_{\text {acetate }} \mathrm{l}^{-1}(\mathrm{pH} 6.4$ ), and the cathode strips contained $0.08 \mathrm{~mol}$ Tris $1^{-1}$ and

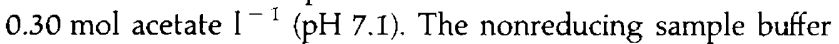
contained SDS at a ratio of 4:I; Nonidet P40 (Sigma Chemical Co., Deisenhofen) to ensure good separation and clearly defined bands (Swack et al., 1987). The lyophilized pituitary and urinary proteins were dissolved in sample buffer and $25 \mu \mathrm{g}$ and $450 \mu \mathrm{g}$ total proteins, respectively, were applied to the gel for electrophoresis. The amounts of $\mathrm{LH}$ and FSH recovered after electrophoresis were $74 \%$ and $53 \%$, respectively, based on the measurement of bioactivity in initial sample extracts and in pooled gel eluates. To determine molecular masses a LMW-MW calibration kit (Pharmacia) was used.

IEF. This was performed within a $\mathrm{pH}$ gradient from 3 to 10 on Precote ${ }^{\circledR}$ slab gels $(120 \mathrm{~mm} \times 120 \mathrm{~mm} \times 0.5 \mathrm{~mm})$ precast with $6.2 \%(\mathrm{v} / \mathrm{v})$ ampholyte (Serva, Heidelberg). The anode solution comprised $3.4 \mathrm{mg}$ aspartic acid $\mathrm{ml}^{-1}$ and $3.6 \mathrm{mg}$ L-glutamic acid $\mathrm{ml}^{-1}$, while the cathode solution contained $4.4 \mathrm{mg}$ L-arginine base $\mathrm{ml}^{-1}, 3.6 \mathrm{mg}$ L-lysine base $\mathrm{ml}^{-1}$ and $3 \%(\mathrm{v} / \mathrm{v})$ ethylenediamine. The power supply was set to a constant current of $10 \mathrm{~mA}$ and power of 30 watt, with an upper limit of $2000 \mathrm{~V}$ at $4^{\circ} \mathrm{C}$. After prefocusing for $30 \mathrm{~min}$, the sample was applied in $4 \%(\mathrm{v} / \mathrm{v})$ ampholyte and subjected to electrophoresis for $3.5 \mathrm{~h}$. A pI calibration kit (Serva) was used to determine the $\mathrm{pH}$. The recovery of $\mathrm{LH}$ and FSH after IEF was $83 \%$ and $66 \%$, respectively.

\section{Fixing and staining of pituitary proteins}

The performance of each separation procedure was monitored by staining part of each slab gel with silver (with modifications from Heukeshoven and Dernick, 1988; Rosenbusch et al, 1991) or Coomassie Brilliant Blue R (Neuhoff et al., 1988) so that the proteins could be visualized.

\section{Elution of electrophoresed proteins}

After electrophoresis, slab gels were cut with a scalpel into serial $2.0 \mathrm{~mm}$ slices and placed in an elution buffer $(800 \mu \mathrm{l})$ for at least $48 \mathrm{~h}$ at $4^{\circ} \mathrm{C}$ to allow passive elution of electrophoresed proteins. The elution buffer consisted of $0.01 \mathrm{~mol}$ phosphate $\mathrm{l}^{-1}$, $0.15 \mathrm{~mol} \mathrm{NaCl} \mathrm{l}^{-1}, 2 \mathrm{mmol}$ EDTA $l^{-1}$, and $1 \%(\mathrm{w} / \mathrm{v})$ BSA, $\mathrm{pH} 7.4$ (Miller et al., 1983; Matteri and Ziegler, 1992). The eluates were analysed by an enzymeimmunoassay or bioassay as described below.

\section{Hormone assays}

Eluates of each slice were analysed for bioactive and immunoactive $\mathrm{LH}$ and bioactive $\mathrm{FSH}$. A reference preparation of human gonadotrophin (LER 907) was used as a standard for LH and FSH bioassays. A reference preparation of human urinary LH and hCG (Primogonyl: Schering AG, Berlin) was used as a standard for the LH enzymeimmunoassay.

In vitro LH bioassay. An in vitro bioassay based on LH-dependent testosterone production by dispersed mouse Leydig cells (Van Damme t al., 1974) was used as described to measure marmoset and tamarin LH (Ziegler et al., 1987; Hearn et al, 1988). Intra-assay and interassay coefficients of variation were $8.8 \%$ and $12.4 \%$, respectively. The lowest detectable concentration of LH (LER 907) was 0.05 miu per tube. Serial dilutions of gonadotrophin-containing gel eluates were parallel to those of the standard preparation.

Testosterone production was measured by a radioimmunoassay using a ${ }^{3} \mathrm{H}$-labelled sheep antiserum raised against testosterone-3-carboxy-methyl-oxine (kindly supplied by $R$. Webb, Edinburgh) at an initial dilution of 1:250 000 . 
In vitro FSH bioassay. FSH was measured by an in vitro bioassay based on the production of cAMP during short-term incubation of rat granulosa cells (Hillier and de Zwart, 1982). In brief, ovaries were collected from female Sprague-Dawley rats (killed by cervical dislocation) that were 21-22 days old and that had been implanted with capsules containing diethylstilbestrol (DES, Sigma) for 5 days. Ovaries were transfered to Dulbecco's modified Eagle's medium and finely minced in a glass tube. The resulting cell suspension was washed three times and cells were diluted to give approximately 80000 cells per $500 \mu \mathrm{l}$ per tube. Cells were incubated in glass tubes for $1 \mathrm{~h}$ at $37^{\circ} \mathrm{C}$ with the standard preparation (LER 907) or an unknown sample. The incubation was stopped with $1870 \mu \mathrm{l}$ ice-cold ethanol and the tubes kept at $-20^{\circ} \mathrm{C}$ until cAMP was measured.

Cyclic AMP was measured using a cAMP radioimmunoassay kit (IBL, Hamburg). In brief, $125-500 \mu l$ unextracted culture medium was dried under vacuum for at least $2 \mathrm{~h}$. The lyophilisate was reconstituted in $95 \mu \mathrm{l}$ assay buffer (PBS) to which $5 \mu$ l diethylamine-acidanhydride $(1: 2)$ for acetylation was added. Tracer (100 $\mu \mathrm{l}^{125}$ I-labelled cAMP; 40000 c.p.m. per tube) and antiserum $(200 \mu \mathrm{l})$ were added and the sample was incubated for $18 \mathrm{~h}$ at $4^{\circ} \mathrm{C}$. At the end of the incubation, $1 \mathrm{ml}$ polyethylene glycol was added, the tubes were centrifuged at $3500 \mathrm{~g}$ for $20 \mathrm{~min}$, the supernatant was decanted and the radioactivity in the pellet was measured. The minimum detectable concentration of cAMP was $0.05 \mathrm{pmol} \mathrm{l}^{-1}$ per tube. Intra-assay and interassay coefficients of variation were $3.9 \%$ and $7.9 \%$, respectively. Serial dilution of pituitary extracts and gel eluates produced displacement curves parallel to that obtained with the FSH standard. Specificity was monitored by adding 7.5 or 75 miu hCG to control tubes and assessing the cellular response in terms of cAMP production.

Enzymeimmunoassay for $L H$. LH was measured by enzymeimmunoassay using a monoclonal anti-bovine LH antibody and a biotinylated LH/hCG preparation (Meyer et al., 1989: Mutayoba et al., 1990). The antibody (Mab 518 B7), previously described and characterized by Matteri et al. (1987), was kindly provided by J. Roser (University of California, Davis, CA) and was used at a dilution of 1:250 $000(0.04 \mu \mathrm{g}$ per well). The LH/hCG standard was biotinylated according to the method described by Meyer et al. (1989). The assay was performed in 96-well microtitre plates, precoated with sheep anti-mouse immunoglobulin $\mathrm{G}$ ( $1 \mathrm{ng}$ per $350 \mu \mathrm{l}$ per well) for $24 \mathrm{~h}$ at $4^{\circ} \mathrm{C}$, followed by adding $0.5 \mathrm{mg}$ BSA (fraction $V$ per $300 \mu \mathrm{l}$ per well) for $2 \mathrm{~h}$ at room temperature. Before they were assayed, plates were emptied, washed three times and the sample or standard $(0.048-12.5 \mathrm{ng}$ per $50 \mu \mathrm{l}$ per well) and antibody $(100 \mu \mathrm{l}$ per well) were added. After incubation for $18 \mathrm{~h}$, biotin-labelled LH/hCG standard (1 ng per $100 \mu \mathrm{l}$ per well) was added, and the plates were incubated for a further $2 \mathrm{~h}$ at room temperature. Plates were decanted, not washed, and $20 \mathrm{ng}$ streptavidin-peroxidase (Sigma) in $100 \mu \mathrm{l}$ assay buffer was added. After incubation for $30 \mathrm{~min}$ the plates were washed four times with $350 \mu \mathrm{l} 0.05 \%$ Tween 80 per well. Substrate solution $\left[25 \mathrm{ml}\right.$ substrate buffer ( $100 \mathrm{mmol} \mathrm{CH}{ }_{3} \mathrm{COONa}^{-1}$, pH 5.5, with $0.18 \mathrm{~mol}$ citric acid $\mathrm{I}^{-1}$ ) substrate buffer plus $100 \mu \mathrm{l}$ $\mathrm{CH}_{2} \mathrm{~N}_{2} \mathrm{O} \times \mathrm{H}_{2} \mathrm{O}_{2} \quad 0.94 \mathrm{~mol}^{-1}$ plus $400 \mu \mathrm{l} 0.6 \%$ tetramethyl- benzidine in dimethylsulfoxide] was added ( $150 \mu \mathrm{l}$ per well) and the plates were incubated in the dark for $30-40 \mathrm{~min}$. The reaction was stopped by adding $50 \mu \mathrm{H}_{2} \mathrm{SO}_{4}$ and the absorbance was measured at $450 \mathrm{~nm}$. Intra-assay and interassay coefficients of variation were $8.5 \%$ and $13.2 \%$, respectively. The minimum detectable concentration of LH/hCG was $0.05 \mathrm{ng}$ per well. Serial dilutions of gonadotrophin-containing gel eluates and pituitary extracts produced displacement curves parallel to those of the standard preparation. The specificity of the LH assay was monitored by adding 5.5 or $55 \mathrm{miu} \mathrm{hFSH}$ to specific wells.

\section{Results}

Since similar results were obtained for each of the two marmosets and tamarins studied, data are presented for one animal of each species. SDS-PAGE of $25 \mu \mathrm{g}$ pituitary and $450 \mu \mathrm{g}$ urinary protein indicates a molecular mass for LH of $36-37 \mathrm{kDa}$, as determined by measuring immunological and biological activity in gel eluates (Fig. 1a,b). Analysis of FSH activity in the same fractions indicates a molecular mass of 36-37 kDa (Fig. 1c,d). In both cases there was no apparent difference between the molecular mass of pituitary and urinary forms. Hormonal data are expressed as the percentage of the peak hormone activity measured to facilitate comparison between individual profiles.

Results of equivalent SDS-PAGE analysis of tamarin pituitary protein extracts (Fig. 2) also indicate molecular masses of approximately $36 \mathrm{kDa}$ for both $\mathrm{LH}$ and $\mathrm{FSH}$, although a smaller band of LH activity corresponding to a molecular mass of $33 \mathrm{kDa}$ was also present. Additional immunological activity corresponding to a molecular mass or $16-17 \mathrm{kDa}$, similar to that obtained after guanidine-induced dissociation (bands at 16 and $25 \mathrm{kDa}$, data not shown), can be assumed to reflect subunit activity.

Profiles of LH and FSH bioactivity following analysis of marmoset pituitary (Fig. 3a) and urinary (Fig. 3b) protein by IEF indicate that there are molecular variants (isoforms) of both gonadotrophins (Fig. 3). Profiles for LH in pituitary and urine extracts exhibited a similar overall range in $\mathrm{pH}$ values, as well as demonstrating considerable activity at the high end of the $\mathrm{pH}$ range ( $\mathrm{pH} 7.0-8.5$ ). In contrast, the isoelectric properties of urinary and pituitary FSH were different, with FSH in urine demonstrating a more acidic isoelectric profile than that of the pituitary hormone (maximum activities: $\mathrm{pH} 5.3$ and $\mathrm{pH} 5.8$, respectively).

Data for IEF-PAGE of pituitary protein from a cotton-top tamarin show that $\mathrm{LH}$ isoforms were distributed over a wide $\mathrm{pH}$ range from 3.8 to 8.5 , whereas FSH was measured over a more acidic range, with maximum activity occurring at $\mathrm{pH} 5.3$ (Fig. 4).

SDS-PAGE of pituitary proteins from rhesus monkeys indicated a molecular mass of $36 \mathrm{kDa}$ for both $\mathrm{LH}$ and FSH, and IEF revealed a wider, more basic band of LH activity (range, 4.5-8.5; peak, 7.2) compared with that of FSH (range, 5.0-7.5; peak, 5.4). Results are not shown but correspond well with those previously published for this species (Matteri et al., 1992). 
(a) $\quad 36-37 \mathrm{kDa}$

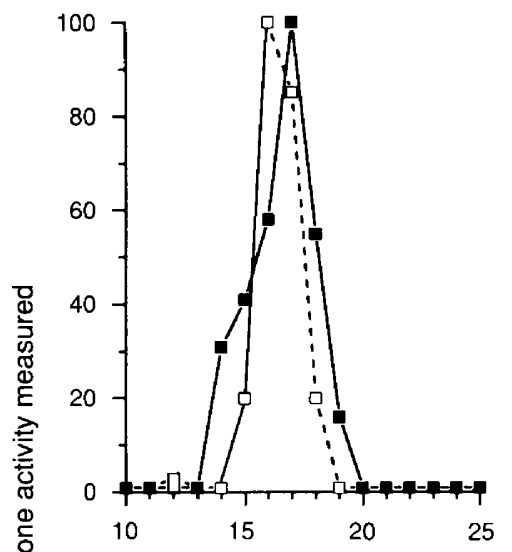

(c) $\quad 36-37 \mathrm{kDa}$

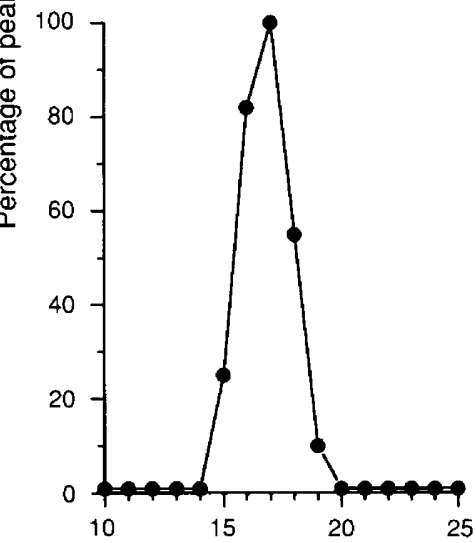

(b)

36-37 kDa

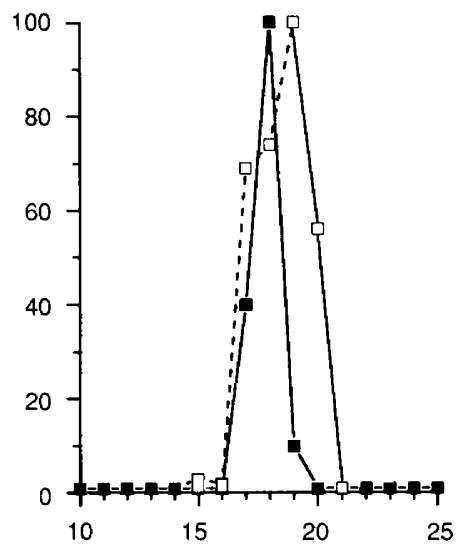

(d)

$36-37 \mathrm{kDa}$

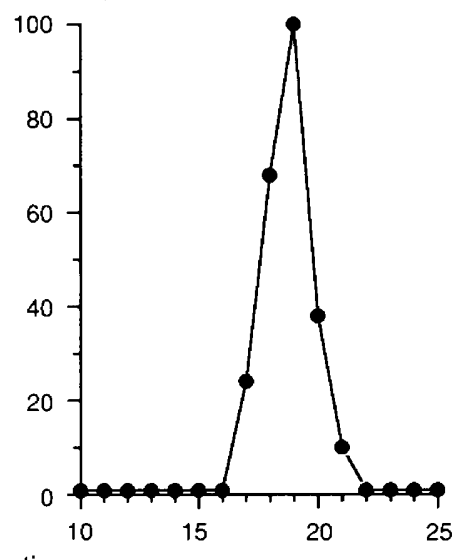

Fig. 1. LH immunoactivity ( $\bullet$ ) and bioactivity ( .) and FSH bioactivity ( $\bullet$ ) in eluates of gel slices after nonreducing SDS-PAGE of marmoset $(a, c)$ pituitary and (b, d) urinary proteins. Data are expressed relative to the highest hormone activity measured $(100 \%)$. For pituitary protein analysis, values representing $100 \%$ were $55.2 \mathrm{ng}, 233 \mathrm{miu}$ and $48 \mathrm{miu}$ per eluate for immunoreactive $\mathrm{LH}$ and bioactive $\mathrm{LH}$ and $\mathrm{FSH}$, respectively; corresponding values for immunoreactive and bioactive LH and FSH bioactivity in urine were $12 \mathrm{ng}, 42 \mathrm{miu}$ and $6 \mathrm{miu}$ per eluate, respectively.

\section{Discussion}

This study presents information on the molecular masses and isoelectric properties of LH and FSH in the common marmoset and cotton-top tamarin. The analysis of pituitary and urinary proteins was based on nonreducing SDS-PAGE and IEF-PAGE followed by hormone assays of gel eluates, as originally described by Matteri and Ziegler (1992). The present results extend the application of this approach to protein analysis from two callitrichid species and confirm its usefulness in comparative studies of the biological properties of nonhuman primate gonadotrophins.

The data from SDS gel electrophoresis indicate molecular masses of between 36 and $37 \mathrm{kDa}$ for $\mathrm{LH}$ and FSH in both species of callitrichid primate. Furthermore, in the marmoset, the molecular masses of pituitary and urinary forms of each gonadotrophin were apparently the same. The molecular mass obtained for rhesus monkey (pituitary) LH and FSH was also similar $(36 \mathrm{kDa})$ and in agreement with previous findings of Matteri and Ziegler (1992). Other data on the molecular masses of pituitary proteins in Callitrichidae are not available, although a preliminary report by Ziegler and Matteri (1991) describes the presence of two molecular forms of LH in urine from the cotton-top tamarin, one with a molecular mass of $38 \mathrm{kDa}$ and the other of $29 \mathrm{kDa}$. Since the present results for tamarin pituitary extracts also indicate two molecular forms of $\mathrm{LH}$ ( 33 and $36 \mathrm{kDa}$ ), both studies support the existence of polymorphism of LH in this species. However, no evidence for polymorphism of cotton-top tamarin FSH or of either gonadotrophin in the marmoset was obtained.

In addition to the presence of a second molecular form of $\mathrm{LH}$, immunoreactivity (but not bioactivity) in the $16-17 \mathrm{kDa}$ range was also detected in cotton-top tamarin pituitary extracts. Although the studies were carried out under 
(a)

$36 \mathrm{kDa}$

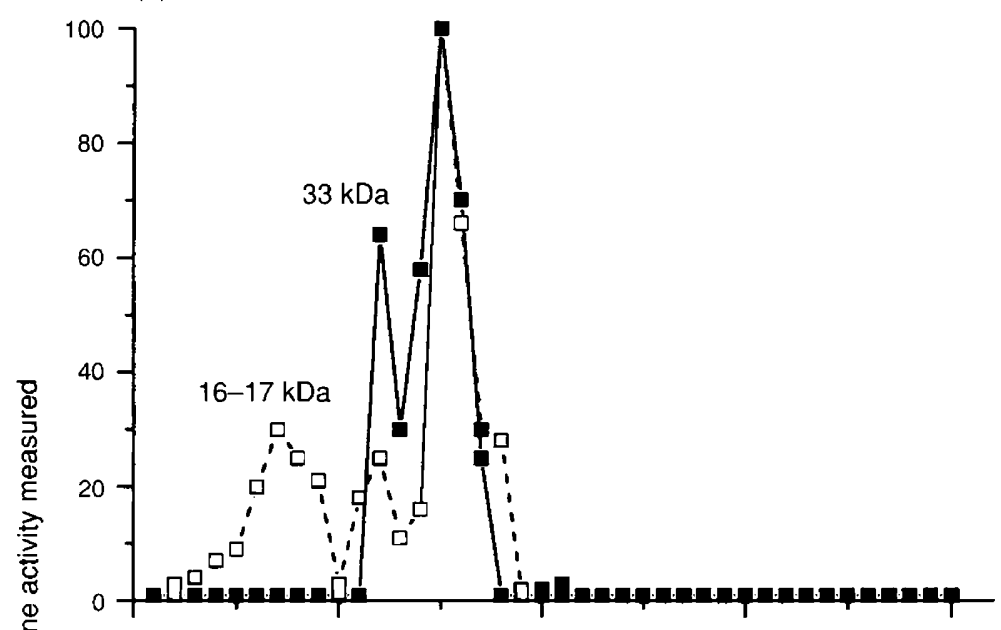

(b)

$36 \mathrm{kDa}$

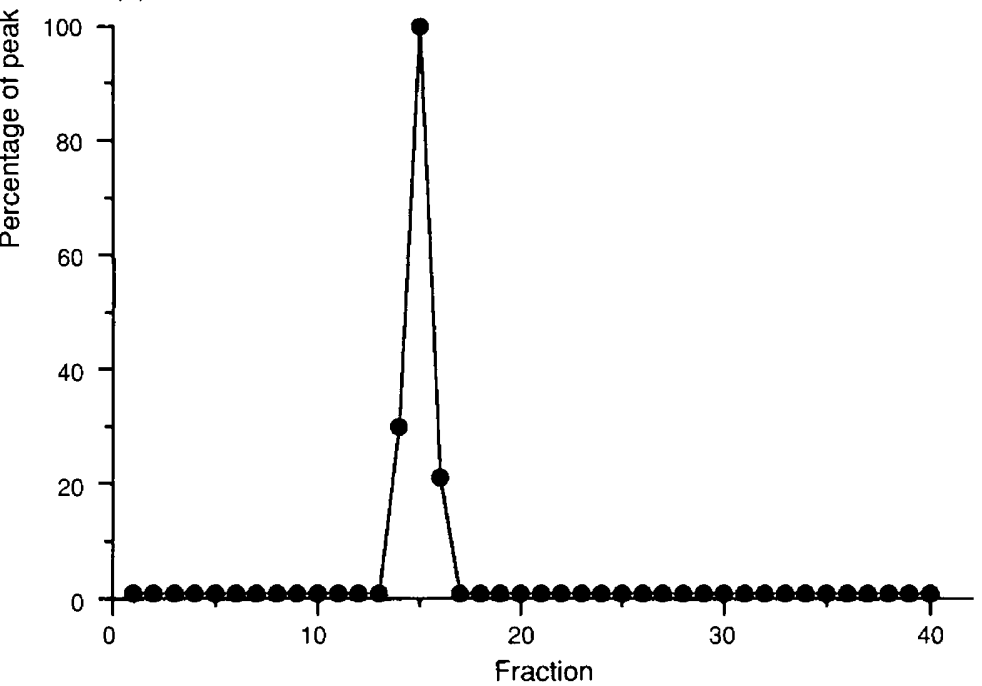

Fig. 2. (a) LH immunoactivity ( $\square$ ) and bioactivity $(\square)$ and (b) FSH bioactivity ( in eluates of gel slices after nonreducing SDS-PAGE of tamarin pituitary proteins. Values representing maximum hormone activity (100\%) were $52 \mathrm{ng}, 150 \mathrm{miu}$ and 16.6 miu per eluate for immunoactive and bioactive $\mathrm{LH}$ and bioactive $\mathrm{FSH}$, respectively.

non-reducing conditions, it would appear that this additional peak represents LH subunit activity. Treatment of pituitary extracts with guanidine $-\mathrm{HCl}$ (a procedure known to induce subunit dissociation) before electrophoresis (data not shown) resulted in two well-defined peaks of immunoactivity but not bioactivity, one of which corresponded to a molecular mass of $16 \mathrm{kDa}$. Furthermore, a similar molecular mass $(17 \mathrm{kDa})$ for the $\beta$ subunit of rhesus monkey pituitary LH following guanidine $-\mathrm{HCl}$ treatment has been reported by Matteri and Ziegler (1992). Although nonreducing buffers were used, it is still possible that certain steps of the procedures carried out in the present study resulted in the partial dissociation of $\mathrm{LH}$ subunits. The reason for the detection of subunit immunoactivity for tamarin LH but not for marmoset or rhesus monkey LH under similar experimental conditions is, however, unclear.
The assay of gonadotrophins in gel eluates after IEF revealed numerous peaks of activity for both $\mathrm{LH}$ and $\mathrm{FSH}$, thus indicating that there are multiple molecular variants or isoforms of each hormone. In all preparations examined, irrespective of species, FSH eluted over a narrower and more acid $\mathrm{pH}$ range than did LH. A high apparent negative charge for FSH in relation to LH has also been reported for both pituitary and urinary protein extracts in rhesus monkeys (Matteri and Ziegler, 1992) and in humans (Miller et al., 1983; Padmanabhan et al., 1987; Mason et al., 1992; Stanton et al., 1992). It has been well documented that this reflects an abundance of FSH isoforms containing relatively large amounts of sialic acid for various species (Peckham et al., 1973; Bogdanove et al., 1974; Grimek ef al., 1979; Blum and Gupta, 1980; Chappel et al., 1983; Mason et al., 1992), and can be assumed to apply to the present results for the marmoset and tamarin. 


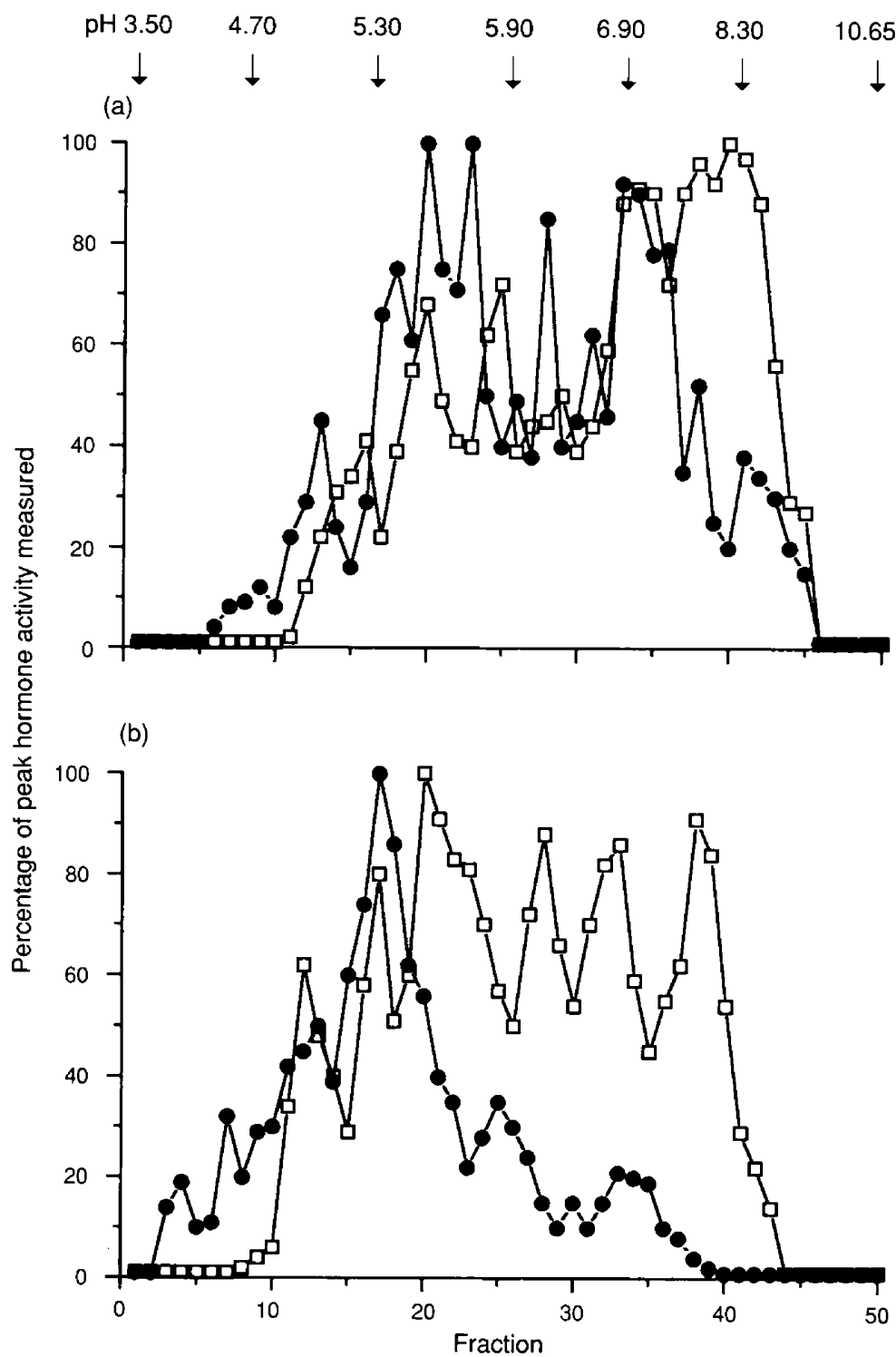

Fig. 3. Isoelectric focusing PAGE of marmoset gonadotrophins, indicating $\mathrm{LH}(\square)$ and FSH ( bioactivity in (a) pituitary and (b) urine. Values representing maximum hormone activity (100\%) were $76.5(\mathrm{LH})$ and $44.0 \mathrm{miu}(\mathrm{FSH})$ per eluate for pituitary extracts and $21.0(\mathrm{LH})$ and $7.2 \mathrm{miu}(\mathrm{FSH})$ per eluate for urinary samples.

The data for the marmoset also indicate the presence of multiple forms of biologically active $\mathrm{LH}$ and FSH in urine. A comparison of profiles of pituitary and urinary proteins reveals little difference between the IEF profiles for LH but a clear shift in the profile towards the acidic range for urinary FSH. Similar findings that urinary FSH demonstates a more acidic isoelectric profile relative to pituitary FSH have also been described for rhesus monkeys (Matteri et al., 1992). The reasons for this are not clear but may be explained in terms of post-translational glycosylation in the liver resulting in addition of sulfate and sialic acid moieties (Graham and Gottschalk, 1960; Smith and Baenziger, 1988).

Minor qualitative differences in the IEF profiles between the two species were also evident, although interpretation is difficult owing to the various factors (for example age, repro- ductive status and grade of glycosylation) influencing the isoelectric properties of gonadotrophic hormones (Wide, 1985, 1989; Keel and Grotjan, 1989; Wilson et al., 1990). Although the marmosets and tamarins from which material was collected were adult females of similar ages (2-5 years) and not pregnant, it is unlikely that they were matched for stage of cycle; thus, direct comparison of the IEF results may be misleading.

In conclusion, this study provides initial data on the biochemical properties of pituitary and urinary LH and FSH in callitrichid primates. Information of this kind will be useful in preparing reagents for the development of improved and much needed immunological assays to detect gonadotrophins in these species. Furthermore, the isolation of various $\mathrm{LH}$ and FSH isoforms provides the opportunity to investigate the biological 


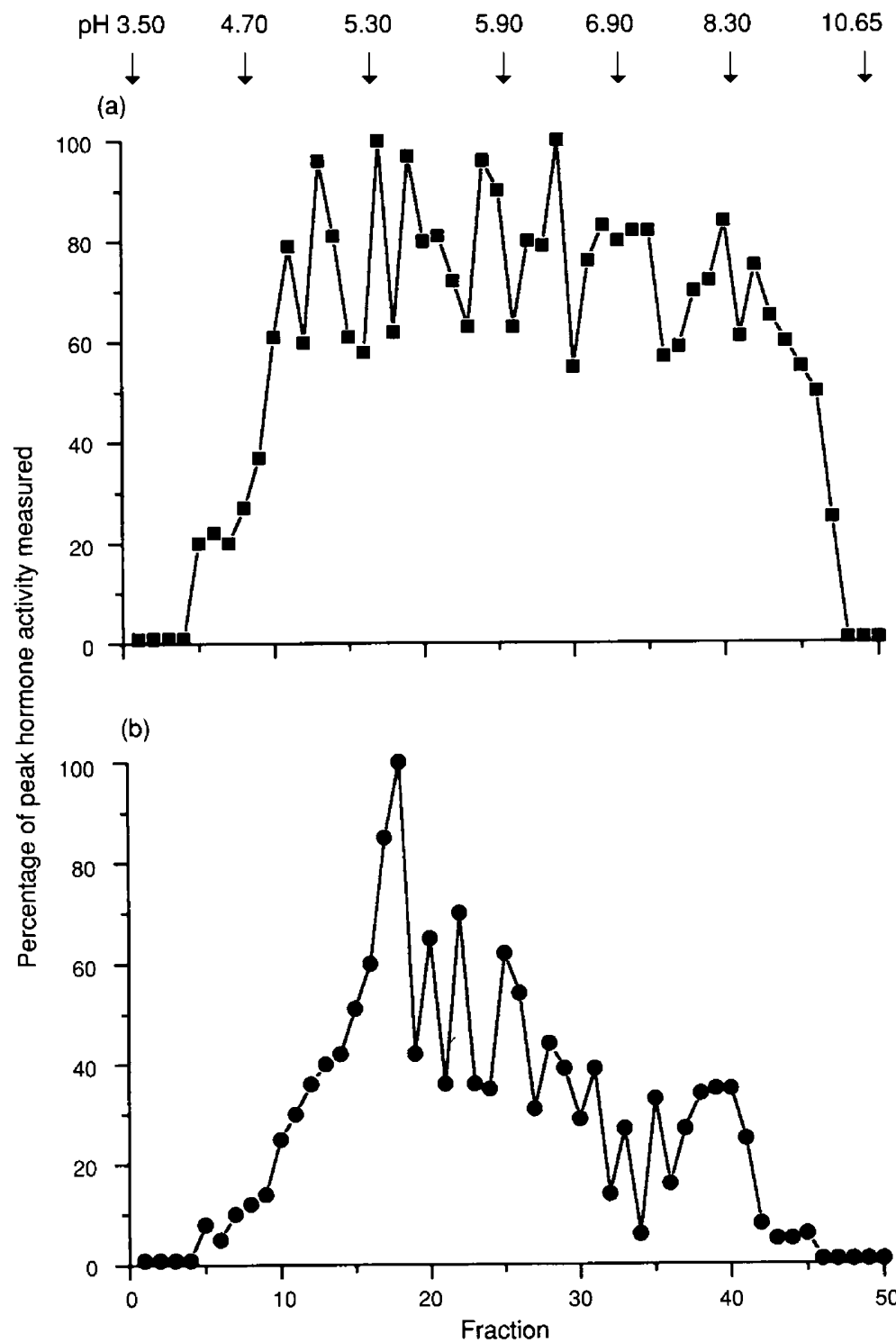

Fig. 4. Isoelectric focusing PAGE of tamarin pituitary protein, indicating (a) $\mathrm{LH}$ and (b) $\mathrm{FSH}$ bioactivity in gel eluates. Values representing 100\% were $168 \mathrm{miu}$ per eluate for $\mathrm{LH}$ and 23.2 miu per eluate for FSH.

activity of specific molecular forms of gonadotrophins in cell and follicle culture systems in vitro and should eventually lead to ovarian stimulation protocols in vivo.

The authors thank M. Besanko for her valuable assistance in establishing the in vitro bioassay for FSH. They also thank S. Schlote for advice on the use of the LH bioassay and J. Hagedorn for skilled technical support. The human pituitary standard preparation (LER 907) was generously supplied by the National Hormone and Pituitary Program (NHPP) 5390, Rockville, MD. This study was supported by the German Research Council (DFG) Ho 1391/1-1.

\section{References}

Blum W and Gupta D (1980) Age and sex-dependent nature of the polymorphic forms of rat pituitary FSH: the role of glycosylation Neuroendocrinology Letters 2 357-365
Bogdanove EM, Campbell GT and Peckham WD (1974) FSH pleomorphism in the rat - regulation by gonadal steroids Endocrine Research Communication 1 87

Chappel SC, Ulloa-Aguirre A and Coufitaris C (1983) Biosyntheis and secretion of follicle-stimulating hormone Endocrinology 4 179-211

Graham ERB and Gottschalk A (1960) Studies on mucoproteins I. The structure of the prosthetic group of ovine submaxillary gland mucoprotein Biochemistry Biophysics Acta 38 513-524

Grimek HJ, Gorski J and Wentworth BC (1979) Purification and characterization of bovine FSH: comparison with ovine FSH Endocrinology 104140

Hearn JP, Hodges JK and Gems S (1988) Early secretion of chorionic gonadotrophin by marmoset embryos in vivo and in vitro Journal of Endocrinology $119249-255$

Heukeshoven J and Dernick R (1988) Improved silver staining procedure for fast staining in the Phast System Development unit Electrophoresis 1 28-32

Hillier SG and de Zwart FA (1982) Androgen/antiandrogen modulation of cyclic AMP-induced steroidogenesis during granulosa cell differentiation in tissue cuiture Molecuiar and Cellular Endocrinology 28 347-361 
Keel BA and Grotjan HE (1989) Luteinizing hormone microheterogeneity. Microheterogeneity of the Glycoprotein Hormones pp 149-184 Eds BA Keel and HE Grotjan. CRC Press, Boca Raton.

Livesey JH, Roud HK, Metcalf MG and Donald LRA (1983) Glycerol prevents loss of immunoreactive follicle-stimulating hormone and luteinizing hormone from frozen urine Journal of Endocrinology $98381-384$

Mason M, Fonseca E, Ruiz J, Morán C and Zarate A (1992) Distribution of follicle-stimulating hormone and luteinizing hormone isoforms in sera from women with primary ovarian failure compared with that of normal reproductive and postmenopausal women Fertility and Sterility $\mathbf{5 6}$ 60-65

Matteri RL and Papkoff H (1987) Characterization of equine luteinizing hormone by chromatofocusing Biology of Reproduction 36 261-269

Matteri RL and Ziegler TE (1992) Detection of nonhuman primate gonadotropins in polyacrylamide gels: an altemative to the western blot American Journal of Primatology 26 155-166

Matteri RL, Roser JF, Baldwin DM, Lipovetsky V and Papkoff H (1987) Characterization of a monoclonal antibody which detects luteinizing hormone from diverse mammalian species Domestic Animal Endocrinology 4 157-165

Matteri RL, Bridson WE, Dierschke DJ, Wegner FH and Durning $\mathbf{M}$ (1992) The secretion of bioactive and immunoreactive follicle-stimulating hormone (FSH) and luteinizing hormone (LH) throughout the menstrual cycle of the rhesus monkey (Macaca mulatta) American Journal of Primatology 26 243-257

Meyer HHD, Sauerwein H and Mutayoba BM (1989) Immunoaffinity chromatography and a biotin-streptavidin amplified enzymeimmunoassay for sensitive and specific estimation of estradiol-17ß Joumal of Steroid Biochemistry $35262-269$

Miller C, Ulloa-Aguirre A, Hyland L and Chappel SC (1983) Pituitary folliclestimulation hormone heterogeneity: assessment of biologic activities of each follicle-stimulating hormone form Fertility and Sterility 40 242-247

Mutayoba BM, Meyer HHD, Schams D and Schallenberger E (1990) Development of a sensitive enzyme immunoassay for $\mathrm{LH}$ determination in bovine plasma using the streptavidin-biotin technique Acta Endocrinologica 122 $227-232$

Neuhoff V, Amold N, Traube D and Erhardt W (1988) Improved staining of proteins in polyacrylamide gels including isoelectric focussing gels with clear background at nanogram sensitivity using Coomassie Brilliant Blue G-250 and R-250 Electrophoresis 9 255-256

Padmanabhan V, Chappel SC and Beitins IZ (1987) An improved in vitro bioassay for follicle-stimulation hormone (FSH) suitable for measurement of FSH in unextracted human serum Endocrinology 121 1089-1098

Peckham WD, Yamaji T, Dierschke DJ and Knobil E (1973) Gonadal function and the biological and physicochemical properties of FSH Endocrinology 92 $1660-1666$

Rosenbusch J, Küderling I and Fuchs E (1991) Social status in tamarins is reflected by urinary protein pattern Primate Report 30 25-28

Smith PL and Baenziger JU (1988) A pituitary $N$-acetylgalactotransferase that specifically recognizes glycoprotein hormones Science 242 930-933

Stanton PG, Robertson DM, Burgon PG, Schmauk-White B and Hearn MT (1992) Isolation and physicochemical characterization of human follicle-stimulating hormone isoforms Endocrinology 130 2820-2832

Swack JA, Nakatsuji T, Ito K and Tsuji K (1987) Preservation of membrane glycoprotein labile epitopes during western blotting with monoclonal antibodies BioTechniques 5 564-571

Van Damme MP, Robertson DM and Diczfalusy E (1974) An improved in vitro bioassay method for measuring luteinizing hormone (LH) activity using mouse Leydig cell preparations Acta Endocrinologica 77 655-671

Wide L (1985) Median charge and charge heterogeneity of human pituitary FSH, LH and TSH. II. Relationship to sex and age Acta Endocrinologica 109 190-197

Wide L (1989) Follicle-stimulating hormones in anterior pituitary glands from children and adults differ in relation to sex and age Journal of Endocrinology $123519-529$

Wilson CA, Leigh AJ and Chapman AJ (1990) Gonadotrophin glycosylation and function Journal of Endocrinology 125 3-14

Ziegler TE and Matteri RL (1991) Polymorphism of urinary luteinizing hormone (LH) in the cotton-top tamarin (Saguinus oedipus) by SDS-polyacrylamide gel electrophoresis (PAGE) Biology of Reproduction Abstract Series 4436

Ziegler TE, Bridson WE, Snowdon CT and Eman S (1987) Urinary gonadotrophin and estrogen excretion during postpartum oestrus, conception and pregnancy in cotton-top tamarin (Sanguinus oedipus oedipus) American Journal of Primatology 12 127-140 